\title{
Thyroid Hormone Signaling in Embryonic Stem Cells: Crosstalk with the Retinoic Acid Pathway
}

\author{
Mercedes Fernández ${ }^{1,+}+{ }^{\circ}$, Micaela Pannella ${ }^{2,+}$, Vito Antonio Baldassarro ${ }^{3}{ }^{\circ}$, \\ Alessandra Flagelli ${ }^{3}{ }^{-0}$, Giuseppe Alastra $^{3}$, Luciana Giardino ${ }^{1,2}$ and Laura Calzà ${ }^{1,2,3, *}$ \\ 1 Department of Veterinary Medical Science, University of Bologna, Via Tolara di Sopra, 50, \\ 40064 Ozzano Emilia, BO, Italy; mercedes.fernandez@unibo.it (M.F.); luciana.giardino@unibo.it (L.G.) \\ 2 Fondazione IRET, Via Tolara di Sopra, 41/E, 40064 Ozzano Emilia, BO, Italy; micaela.pannella@gmail.com \\ 3 Interdepartmental Center for Industrial Research in Life Sciences and Technologies, University of Bologna, \\ Via Tolara di Sopra, 41/E, 40064 Ozzano Emilia, BO, Italy; vito.baldassarro2@unibo.it (V.A.B.); \\ alessandra.flagelli2@unibo.it (A.F.); giuseppe.alastra2@unibo.it (G.A.) \\ * Correspondence: laura.calza@unibo.it; Tel.: +39-051798776 \\ + These authors contributed equally to this work.
}

Received: 30 October 2020; Accepted: 20 November 2020; Published: 25 November 2020

\begin{abstract}
While the role of thyroid hormones (THs) during fetal and postnatal life is well-established, their role at preimplantation and during blastocyst development remains unclear. In this study, we used an embryonic stem cell line isolated from rat (RESC) to study the effects of THs and retinoic acid (RA) on early embryonic development during the pre-implantation stage. The results showed that THs play an important role in the differentiation/maturation processes of cells obtained from embryoid bodies (EB), with thyroid hormone nuclear receptors (TR) (TR $\alpha$ and TR $\beta$ ), metabolic enzymes (deiodinases 1, 2,3) and membrane transporters (Monocarboxylate transporters-MCT- 8 and 10) being expressed throughout in vitro differentiation until the Embryoid body (EB) stage. Moreover, thyroid hormone receptor antagonist TR (1-850) impaired RA-induced neuroectodermal lineage specification. This effect was significantly higher when cells were treated with retinoic acid (RA) to induce neuroectodermal lineage, studied through the gene and protein expression of nestin, an undifferentiated progenitor marker from the neuroectoderm lineage, as established by nestin mRNA and protein regulation. These results demonstrate the contribution of the two nuclear receptors, TR and RA, to the process of neuroectoderm maturation of the in vitro model embryonic stem cells obtained from rat.
\end{abstract}

Keywords: embryonic stem cells; thyroid hormone; nuclear receptors; neuroectoderm; retinoic acid; nestin

\section{Introduction}

Thyroid hormones (THs), both the active form triiodothyronine (T3) and the pro-hormone thyroxine (T4), play key roles in physical and mental development and maturation in all animal species, having multiple and different effects during embryonic, fetal and postnatal life. In humans, this role is well illustrated by the consequences of untreated clinical and subclinical hypothyroidism, which leads to an insufficient supply of maternal THs to the fetus [1]. When occurring in the early stages of pregnancy, maternal hypothyroidism has deleterious effects, in particular on central nervous system (CNS) development, resulting in intellectual disability [2], as dramatically illustrated by the clinical syndrome known as "cretinism" [3].

The cellular action of THs is exerted via genomic and non-genomic mechanisms [4,5]. Genomic effects are mediated by two classes of thyroid hormone nuclear receptors (NRs), TR $\alpha$ and 
TR $\beta$, encoded by THRA and THRB genes [6]. The primary transcript for each gene can be alternatively spliced, generating four different thyroid hormone receptors (TRs) in humans, TR $\alpha 1, T R \alpha 2, T R \beta 1$ and TR $\beta 2$, belonging to the large family of ligand-dependent transcription factors. Each receptor contains three domains: the transactivation domain that interacts with other transcription factors to form complexes that repress or activate transcription; the DNA-binding domain that binds to sequences of promoter DNA known as hormone response elements, and a ligand-binding and dimerization domain at the carboxy-terminus. Following ligand binding, TRs heterodimerize mainly with retinoid $X$ receptors (RXRs), a family of NRs consisting of three members, $R X R \alpha, R X R \beta$ and $R X R \gamma$. The binding of the NR dimers to target genes results in either suppression or induction, depending on ligand presence and the recruited co-factors [7]. Moreover, a complex biochemical machinery consisting of TH membrane transporters (MCT8, MCT10), synthesis (D1 and D2) and degrading (D3) enzymes of the active form T3 are also present in almost all cells to guarantee an appropriate concentration of intracellular T3 [8]. Finally, extracellular TH receptors, namely integrin $\alpha \mathrm{v} \beta 3$, also mediate TH effects during development and adulthood [9].

Retinoic acid (RA) also plays key roles in early development. RA is a derivative of vitamin A, an essential nutrient which cannot be synthesized by the embryo and must be acquired from the maternal circulation through the placenta [10]. The cellular action of RA is also mediated by NRs belonging to the same superfamily as TRs. RA receptors (RARs), in fact, form heterodimers with RXRs and TRs, bind to RA-responsive elements (RAREs), and regulate expression of the target genes [11].

In humans, the onset of fetal thyroid function occurs at week 12 and is completed by 18 weeks of gestation, while vitamin A can not be synthesized by the embryo, which can instead produce the active form of RA. However, both THs and RA of maternal origin mediate very early developmental events. The maternal-fetal exchange of these factors begins though the transient structure yolk sac and the fetal exocoelomic cavity [12-14], after which the presence of different classes of TH membrane transporters in the placenta, such as organic anion transporting polypeptides, monocarboxylate transporters, and transthyretin for THs, together with the placental TH inactivating enzyme deiodinase 3 (D3), guarantee- the feto-maternal TH equilibrium [15]. The role of placental retinoic binding proteins (RBPs), transthyretin and other proteins (Strat6, CRBPI) as vitamin A trans-placental carriers is still debated [10].

Sporadic data indicates that pre-implantation embryos are also TH- and RA-sensitive. For example, THs are present in ovarian follicular fluid [16], TRs are expressed up to the blastocyst stage in the bovine preimplantation embryo [17], and the eight-cell morula and inner mass in human embryos express low levels of TR $\alpha$ and TR $\beta$ [18]. More generally, the in vitro exposure of bovine embryos to THs significantly increases blastocyst formation, hatching rates, increases the total cell count, and reduces apoptotic cells [19].

Our aim in this study was to explore the potential role of THs and RA in early pre-implant embryonic development, focusing on the possible genomic interaction between the TH and RA receptors. For this purpose, we used embryonic stem cells (ESCs) derived from the inner cell mass of rat blastocyte obtained 4.5 days post coitum. These cells, which are characterized for the ESC bona fide properties [20], can be used as a cell line, and cultured in different conditions as a monolayer or 3D structure (spheroids and embryonic bodies).

\section{Results}

\subsection{RESC Culture Conditions Determine Culture Type and Cell Properties}

ESCs cultured in vitro mimic all the different and timely regulated cellular and molecular processes necessary for the success in blastocyte pre-implantation [19]. To reproduce a number of key processes of this stage, we cultured RESC in different conditions, medium compositions and culture surfaces, yielding RESC for growth in different cell aggregations, exhibiting different cellular and molecular properties. In particular, in the presence of LIF and bFGF, cells growing on ultra-low attachment (ULA) plates proliferated as clusters (CL) and progressively increased in size (Figure 1B). When the 
CL reached a diameter of about $300 \mu \mathrm{m}$ (after 6-7 DIV approximately), they were mechanically split, after which there were two possible approaches: (i) SCML-new medium on standard surfaces treated for cell adhesion, promoting cell proliferation, where cultures exhibited a mixed population of floating clusters (mCL) and single cells (mSC) attached to the surface (Figure 1C); or (ii) SCM without LIF and with bFGF (-LIF/+bFGF) on ULA surfaces. Following this second approach, cells proliferated as large spheroidal cell aggregate structures known as embryonic bodies (EB; Figure 1D) [20,21]. EB induction took 7 days of culture and represented the first step toward three-layer differentiation. When single cells obtained from the EB dissociation were then cultured onto coated surfaces in SCM medium without mitogens, they proliferated and differentiated (Figure 1E). Culture medium contained $10 \%$ of serum in all aforementioned conditions (FBS-ES).

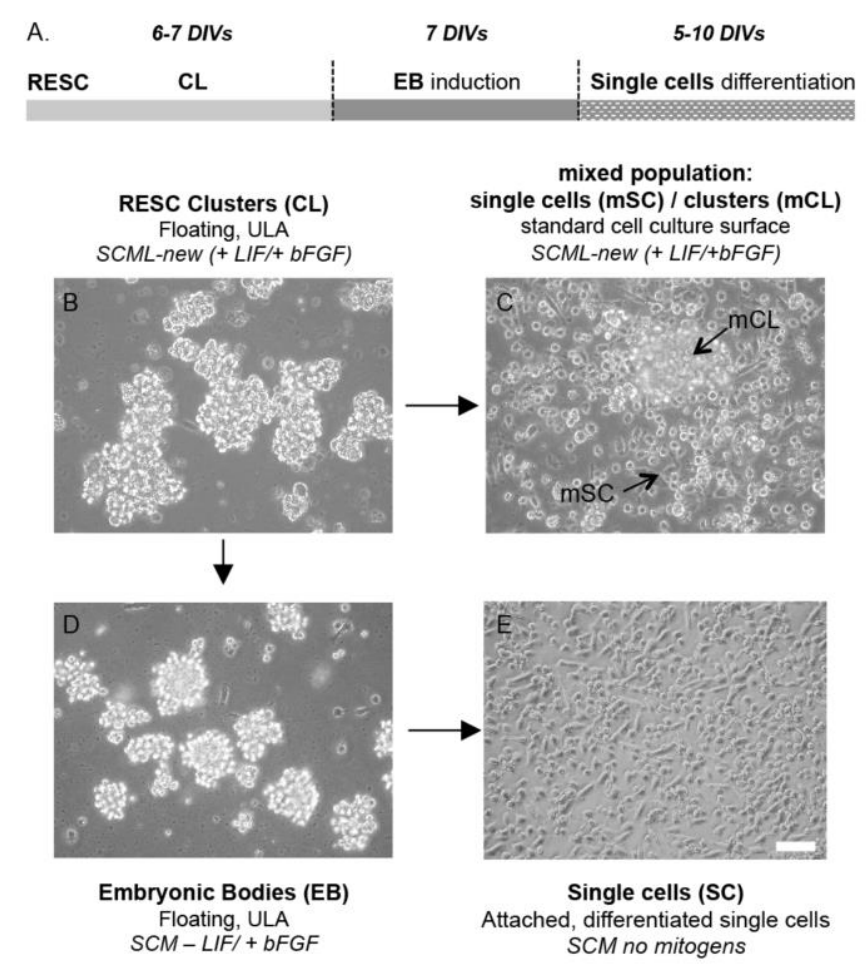

Figure 1. RESC populations and culture conditions. (A). Experimental and temporal approach to obtain the different RESC populations. (B-D). Representative images of cells cultured in different medium compositions and culture conditions are shown in the figure. When RESC grow in SCML-new medium (+LIF/+bFGF) on a ULA surface, cells proliferate as CL, increasing in size over the days in culture (B). Cells resulting from split CL can be either cultured in SCML-new medium (+LIF/+bFGF) on a standard culture surface (Nuclon Delta treated), giving a mixed population of floating clusters (mCL, black arrow in the picture) and attached single cells (mSC, black arrow in the picture) (C), or cultured in SCM medium -LIF/+bFGF on a ULA surface, thus inducing the formation of EB (D). Single cells obtained from the split of EB and cultured on a coated surface spontaneously differentiated (E). Scale bar $100 \mu \mathrm{m}$. Abbreviations: bFGF, basic fibroblast growth factor; EB, embryoid bodies; $\mathrm{CL}$, clusters; LIF, leukemia inhibitory factor; $\mathrm{mCL}$, mixed population clusters; $\mathrm{mSC}$, mixed population single cells; SC, single cells; SCM, stem cell medium; SCML, SCM with LIF; ULA, ultra-low attachment.

RESC properties in the different culture conditions were investigated in terms of pluripotency (Oct4 gene expression and Oct4 protein), inner cell mass differentiation (Afp and Stella gene expression), and cytoskeleton and extracellular matrix (ECM) protein expression (F-actin and laminin). Although pluripotency marker Oct4 was expressed in all culture conditions, the highest Oct4 expression was observed in the clusters obtained from the mixed population ( $\mathrm{mCL}$ ) grown in SCML-new medium in the presence of LIF and bFGF (Figure 2A). Stella mRNA (Figure 2B) and Afp gene expression level strongly increased in EB (Stella five times; Afp around 120-fold CL) compared to all the other cell 
populations (Figure 2C). Interestingly, the expression of these three genes in clusters from the mixed population $(\mathrm{mCL})$, which grew in floating conditions, was higher than the $\mathrm{mSC}$, which grew attached to the plate surface.
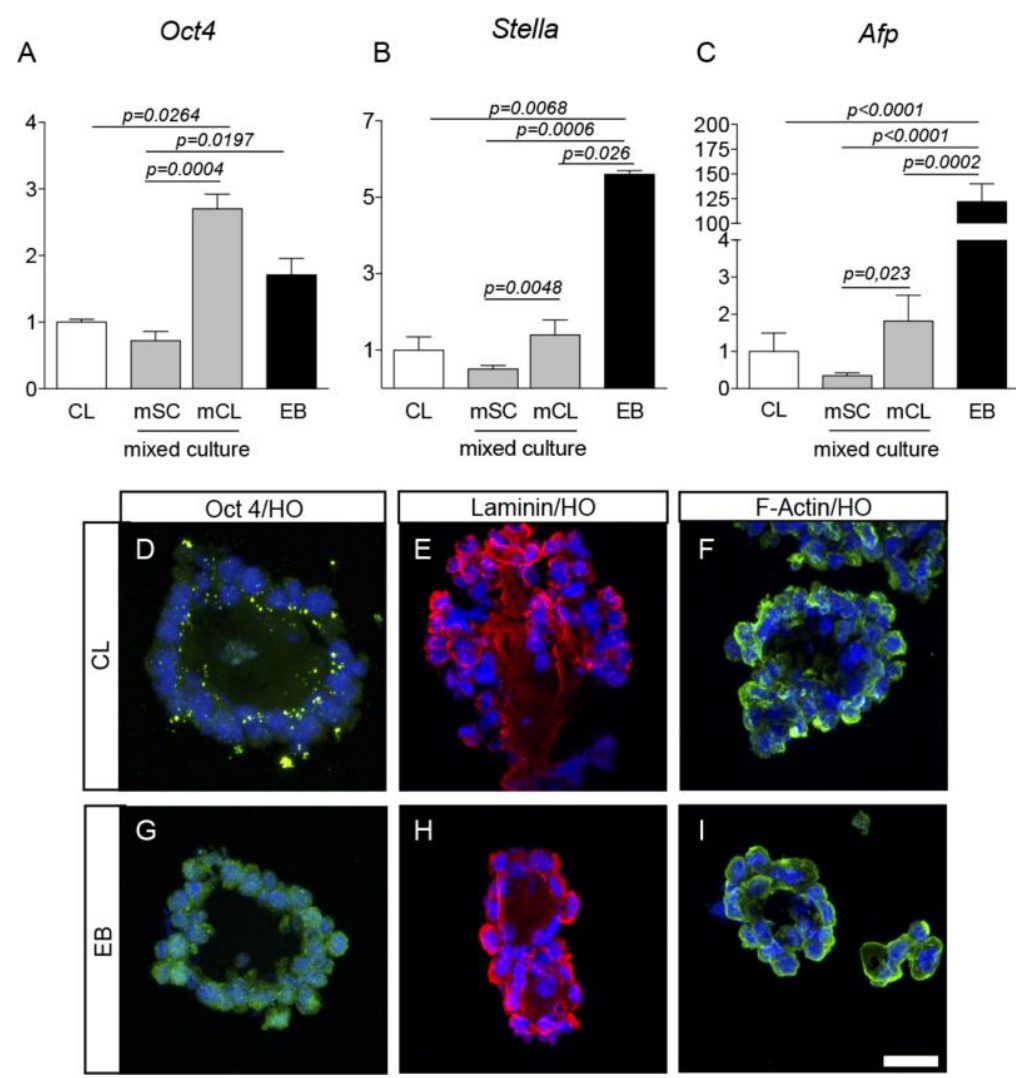

Figure 2. RESC pluripotency and differentiation capabilities. The expression of pluripotency and inner cell mass differentiation markers was studied in RESC: Oct 4 mRNA (A) and protein (D,G); Stella mRNA (B); Alpha fetoprotein mRNA (C); Laminin (E,H) and F-actin (F,I) proteins. Gene expression was assessed by semiquantitative QPCR and the $2^{(-\Delta \Delta C t)}$ method, using CL as reference group. The graphs show mean values \pm SEM of $n=3$ independent experiments. Samples were processed in duplicate. Statistics: One-way ANOVA and Tukey's post test were performed. Significance was set at $p<0.05$. Representative images of CL and EB cryosections stained with the specified antibodies and the nuclear colorant Hoechst 33258 are included in the figure. Scale bar $25 \mu \mathrm{m}$. Abbreviations: Afp, alpha fetoprotein; CL, clusters; EB, embryoid bodies; F-actin, filamentous actin; HO, Hoechst; Oct 4, octamer-binding transcription factor 4 ; $\mathrm{mCL}$, mixed population clusters; $\mathrm{mSC}$, mixed population single cells.

We also investigated the expression of marker proteins in the two culture conditions, which provided the extreme results at mRNA level, i.e., pluripotency-supporting conditions (CL in SCML-new medium and ULA surfaces) and differentiation-promoting conditions (EB in SCM -LIF/+bFGF medium and ULA surfaces). To achieve this, CL and EB cryosections were prepared and processed for ICC as described. Cells displaying Oct4 immunostaining were observed in CL and EB (Figure 2D,G). The cytoskeleton F-actin (Figure 2F,I) and base membrane laminin (Figure 2E,H) proteins were both expressed in CL and EB.

\subsection{Nuclear Receptors and co-Regulator Expression in the Different Culture Conditions}

We then analyzed the gene expression of the entire set of NRs (47 in rat) and co-regulators in the four culture conditions reflecting the differentiation steps using PCR array technology, (see Supplementary Table S1 for the full list of genes and fold regulations). This profile created a clustergram consisting of a 
cluster containing three groups ( $\mathrm{mCL}, \mathrm{CL}$ and $\mathrm{mSC}$ ) with $\mathrm{mCL}$ and $\mathrm{CL}$ in the same sub-cluster, and the EB cells in a separate cluster (Figure 3A).

A

A Cluster analysis

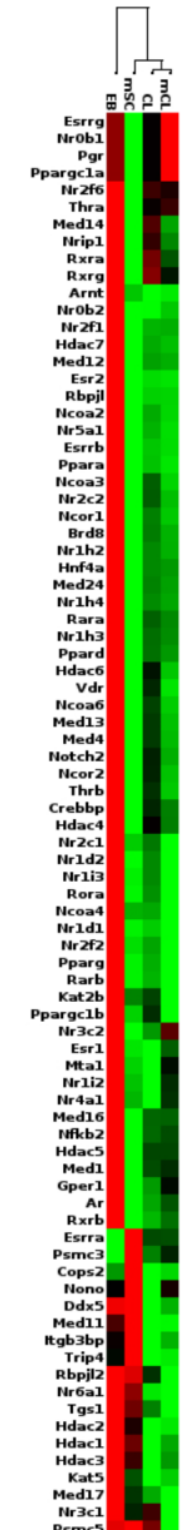

B
List of differentially expressed genes

\begin{tabular}{|l|l|l|l|}
\hline \multirow{2}{*}{ Symbol } & \multicolumn{3}{|c|}{ Fold regulation (compared to CL) } \\
\cline { 2 - 4 } & mCL & mSC & EB \\
\hline Brd8 & -1.19 & -1.57 & 2.05 \\
\hline Esr1 & 1.32 & 1.05 & 2.02 \\
\hline Esr2 & -1.09 & -1.51 & 5.89 \\
\hline Esrrb & -1.06 & -1.19 & 2.32 \\
\hline Gper1 & 1.45 & -1.45 & 2.29 \\
\hline Hnf4a & -1.06 & -1.67 & 2.34 \\
\hline Med12 & -1.04 & -1.38 & 2.25 \\
\hline Med24 & -1.09 & -1.49 & 2.03 \\
\hline Ncoa2 & -1.17 & -1.37 & 2.39 \\
\hline Ncor1 & -1.25 & -1.53 & 2.06 \\
\hline Nr0b2 & 1.18 & -1.01 & 2.79 \\
\hline Nr1d1 & -1.53 & -1.38 & 4.18 \\
\hline Nr1h4 & -1.12 & -1.88 & 2.60 \\
\hline Nr1i3 & -2.84 & -2.33 & 3.18 \\
\hline Nr2f1 & 1.02 & -1.40 & 2.69 \\
\hline Nr2f2 & -1.38 & -1.22 & 2.30 \\
\hline Nr5a1 & -1.40 & -1.94 & 3.81 \\
\hline Ppara & -1.33 & -1.67 & 4.02 \\
\hline Pparg & -1.50 & -1.40 & 2.83 \\
\hline Rarb & -1.38 & -1.31 & 2.66 \\
\hline Rbpjl & -1.02 & -1.29 & 3.29 \\
\hline Rora & -1.58 & -1.53 & 2.36 \\
\hline Rxrg & -1.31 & -2.48 & 1.18 \\
\hline Thrb & -1.82 & -2.51 & 1.88 \\
\hline Vdr & -2.21 & -2.61 & 1.83 \\
\hline & & & \\
\hline
\end{tabular}

C GeneCodis pathway enrichment (KEGG)

Magnitude of expression

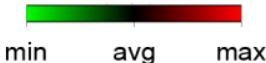

Figure 3. Nuclear receptor and co-regulator expression. The expression of all $47 \mathrm{NRs}$ and 37 co-regulators were analyzed by RT2 PCR array technique and represented as a $\triangle \mathrm{Cq}$ heatmap for each gene in a clustergram showing the maximum (red) and the minimum (green) expression for each gene in the various groups (A). The fold of regulation value for each gene was calculated using CL as a control group, and genes showing more than 2-fold regulations are shown (B). Red color is for genes that are up-regulated whereas green color is for genes that are down-regulated. Bold numbers indicate fold of changes $\geq 2$, both as positive and negative value. These genes were used as inputs for the pathway enrichment analysis using the GeneCodis software, and the results of the analysis is shown (C). Abbreviations: $\mathrm{CL}$, clusters; $\mathrm{Cq}$, threshold cycle; $\mathrm{EB}$, embryoid bodies; $\mathrm{mCL}$, mixed population clusters; mSC, mixed population single cells. 
Of the total of 84 genes of interest, 22 genes were upregulated ( $>2$ fold increase) in EB compared to CL (Brd8, Esr1, Esr2, Esrrb, Gper1, Hnf4a, Med12, Med24, Ncoa2, Ncor1, Nr0b2, Ne1d1, Nr1h4, Nr1l3, Nr2f1, Nr2f2, Nr5a1, Ppara, Pparg, Rarb, Rbpjl, Rora), and one was downregulated in both mCL and mSC compared to CL (Nr1i1). Three genes were downregulated in mSC (Rxrg, Thrb and Vdr) compared to $\mathrm{CL}$, and $V d r$ was also downregulated in mCL. However, all of them increased expression in EB (Figure 3B).

Analyzing the entire list of the differentially expressed genes by pathway enrichment (GeneCodis 4.0), 21 of the 25 inputs were recognized by KEGG pathway analysis, showing TH signaling to be the most represented pathway (Figure 3C, Supplementary Table S2).

\subsection{TH Signaling in RESC in the Different Culture Conditions}

To analyze the expression of the regulators and mediators of TH signaling more in-depth, we then studied the expression level of the TH-converting enzymes (deiodinases D1 and D2, converting inactive T4 to the active T3; deiodinase D3, the inactivating enzyme converting T4 to rT3 and T3 to T2 [4]); TH transporters (MCT8, MCT10), and TH nuclear receptors (TR $\alpha 1, T R \alpha 2, T R \beta)$.

Overall, RESC expressed TH signaling genes and proteins (Figure 4). More specifically, D1 and D2 showed higher mRNA levels in the clusters of the mCL mixed population compared to CL, whereas they were downregulated in the mSC mixed population of single cells (Figure 4A,B), while EB express higher D2 levels compared to CL. Interestingly, the D3 mRNA enzyme was significantly upregulated in both $\mathrm{mCL}$ and $\mathrm{mSC}$ populations (Figure $4 \mathrm{C}$ ).
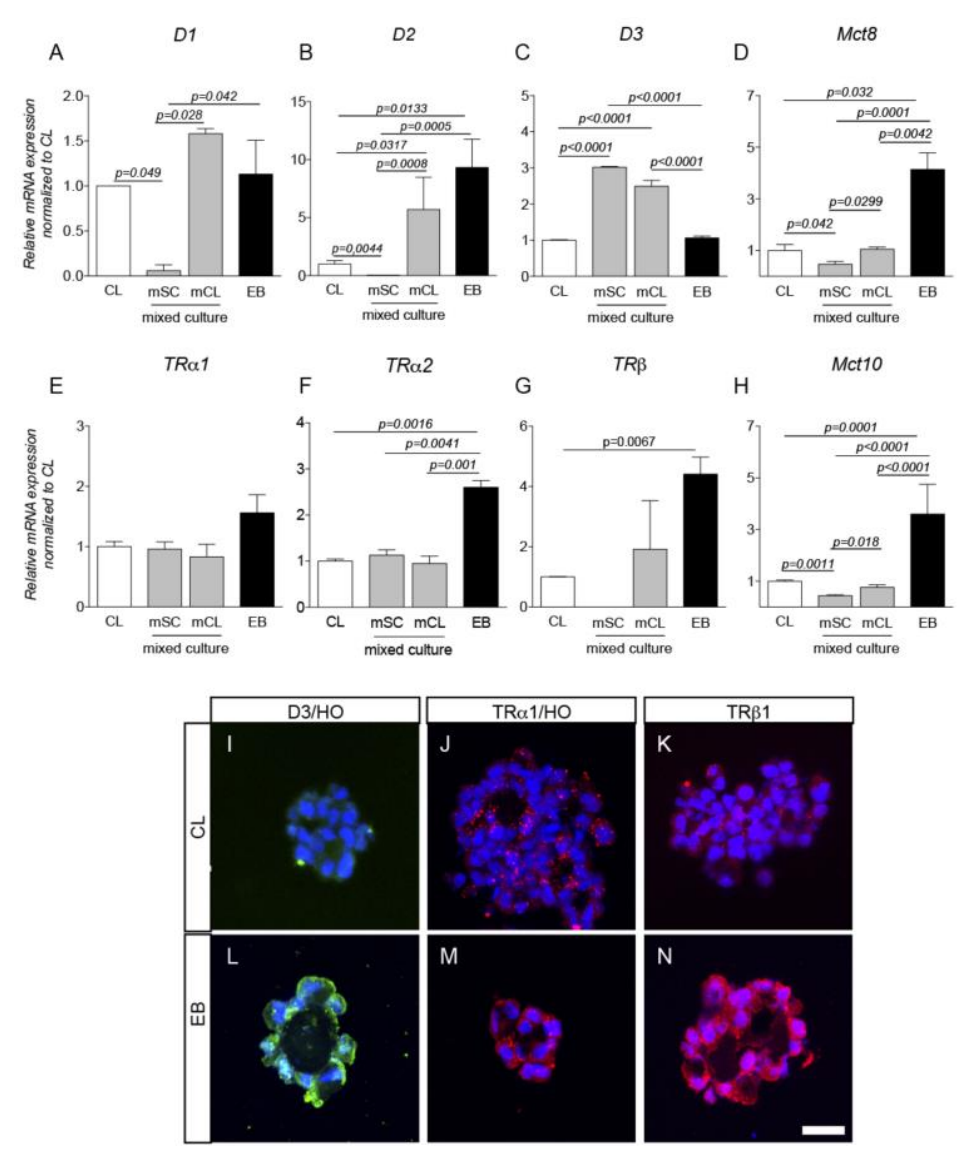

Figure 4. RESC and Thyroid Hormone. RESC gene expression of TH converting enzymes D1, D2, D3 (A-C), transporters MCT8, MCT10 (D,H) and receptors TR $\alpha 1, T R \alpha 2$ and TR $\beta(E-G)$ studied by semiquantitative QPCR and the $2^{(-\Delta \Delta C \mathrm{Ct})}$ method, using CL as reference group. A total of $n=3$ independent experiments were performed; samples were processed in duplicate. Mean values \pm SEM 
have been included in the graphs. Statistical analysis performed: 1- way ANOVA and Tukey's post test $(\mathbf{A}-\mathbf{F}, \mathbf{H})$ and Student's $t$-test $(\mathbf{G})$, results were significant when $p<0.05$. In the figure representative images of D3 enzyme as well as TR $\alpha 1$ - and TR $\beta 1$ - receptor positive cells Hoechst 33258 stained are included (I-N). Scale bar $25 \mu \mathrm{m}$. Abbreviations: CL, clusters; D1, deiodinase enzyme type 1; D2, deiodinase enzyme type 2; D3, deiodinase enzyme type 3; EB, embryoid bodies; HO, Hoechst; MCT8, monocarboxylate transporter 8; MCT10, monocarboxylate transporter 10; TR $\alpha 1$, thyroid hormone receptor alpha 1; TR $\alpha 2$, thyroid hormone receptor alpha 2; TR $\beta$, thyroid hormone receptor beta; $\mathrm{mCL}$, mixed population clusters; mSC, mixed population single cells.

The TH transporters MCT8 and MTC10 were also expressed in RESC; EB in particular showed the higher gene expression of both transporters (Figure 4D-H). The expression of both transporters was also significantly lower in mSC compared to CL and mCL. TR $\alpha 1$ was equally expressed in all RESC growing conditions (Figure 4E), whereas TR $\alpha 2$ and TR $\beta$ mRNA levels were higher in EB (Figure 4F,G). D3, TR $\alpha 1$ and TR $\beta$ immunostaining of CL and EB cryosections is shown in Figure 4 panels I-N. As the figures show, the D3 protein was present in the cell cytoplasm (Figure 4I,L) whereas TR $\alpha 1$ and TR $\beta$ were also distributed throughout the nucleus (Figure 4J,K,M,N).

\subsection{TH Signaling in Germ Layer Lineage: Focus on Neuroectodermal Differentiation}

To explore the potential role of TH signaling in neuroectodermal induction, the EBs were split, and the resulting single cells cultured onto gelatin coated coverslips in SCM medium without mitogens and in the presence of $1 \mu \mathrm{M}$ RA. The neuroectoderm lineage of RESC was initially assessed using the neuroectodermal marker nestin, and representative images of the cell cultures at 5 and 10 DIV are shown in Figure 5A-D. At both analyzed time points, the number of nestin-positive cells was significantly higher in RA-exposed compared to RA-unexposed cells (Figure 5E,F) (5 DIV: $32.89 \pm 2.75$ vs. $50.83 \pm 2.66 ; 10$ DIV: $32.26 \pm 5.97$ vs. $88.85 \pm 3.1$ ). In addition, the number of nestin-positive cells under RA-exposure at 10 DIV was approximately 1.7 times that at 5 DIV. RA-treated nestin-positive cells showed a more differentiated morphology than spontaneously differentiated cells at both 5 and $10 \mathrm{DIV}$, as indicated by the shape of the cells and by the numerous elongations extending from the cell bodies.
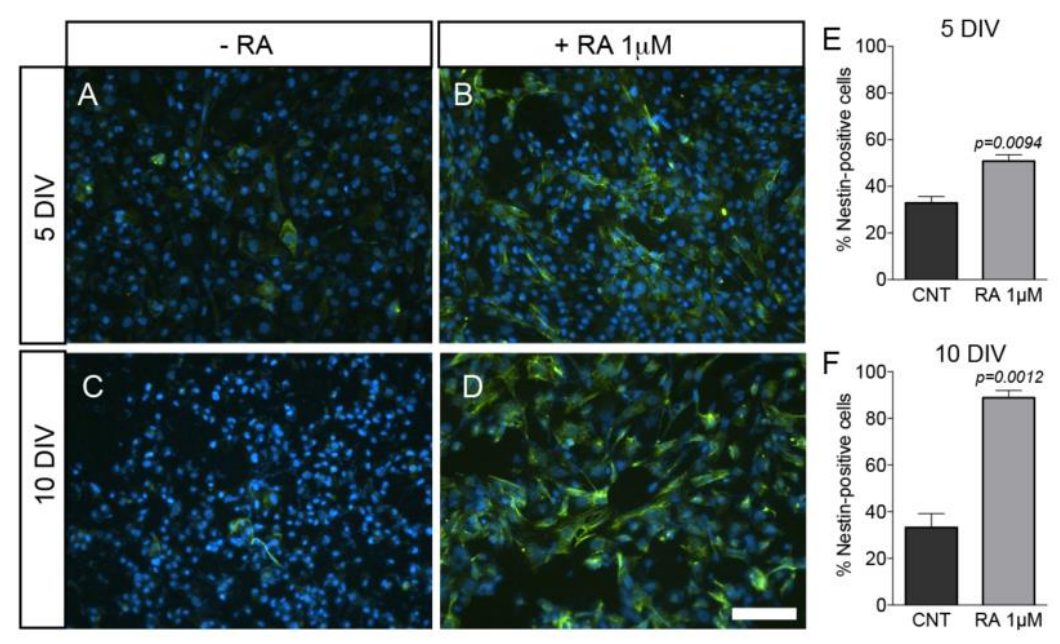

Figure 5. RESC and neuroectoderm lineage. Single cells obtained from the EB split were cultured onto gelatin coated coverslip in SCM medium without mitogens and allowed to differentiate. Representative images of spontaneously differentiated cells $(\mathbf{A}, \mathbf{C})$ or $1 \mu \mathrm{M}$ RA-treated cells for 5 and 10 DIV (B,D) nestin-immunostained (green) and Hoechst 33,258 nuclear-stained cells (blue) are shown. The number of nestin-positive cells was significantly higher in the $1 \mu \mathrm{M}$ RA-treated group of cells at both time points studied (E,F). Statistical analysis performed: Student's $t$-test. Scale bar $100 \mu \mathrm{m}$. Abbreviations: DIV, days in vitro; RA, retinoic acid. 
To explore the possible role of TH signaling in RA-induced neuroectoderm lineage, we used the pharmacological tool TR antagonist 1-850, a selective and high-affinity TR antagonist which blocks T3-mediated interaction of TR $\alpha$ and TR $\beta$ with nuclear receptor coactivator. This molecule prevents TR-mediated genetic effects, without affecting retinoic acid receptor $\alpha(R A R \alpha)$ activity [22]. RESC were exposed to TR antagonist 1-850 in different culture conditions as illustrated in Figure 6A: (a) treatment lasted throughout all differentiation stages, from CL to differentiated single cells; (b) cells were treated only when cells grew as CL; (c) cells were treated during the EB induction period only; (d) cells were treated during the differentiation phase; and (e) cells were not treated at all, thus representing the experimental control group.

A.
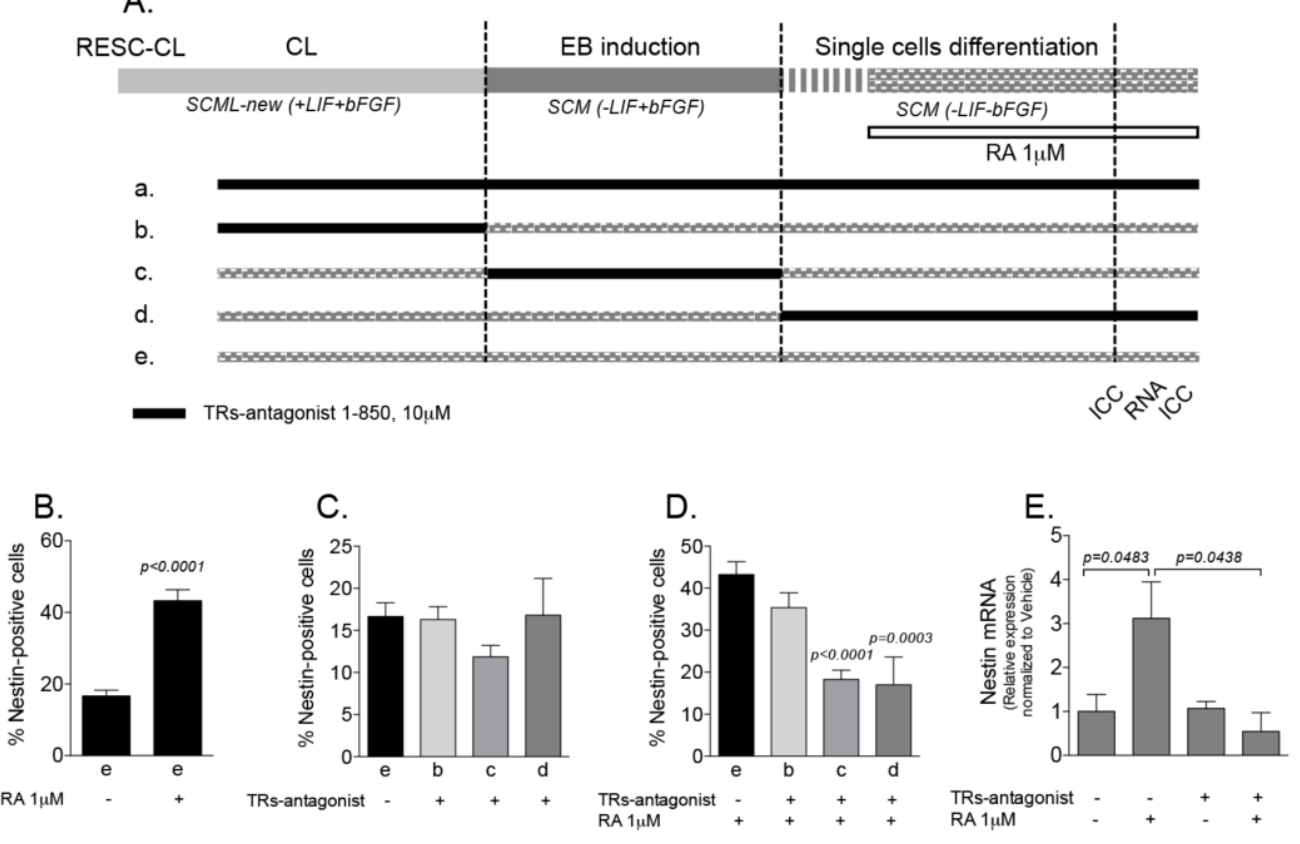

Figure 6. (A). TR antagonist 1-850 and RA treatment experimental design. The diagram shows the experimental conditions used to block T3 binding to its receptors TR $\alpha$ and TR $\beta$ in the different RESC culture conditions. Experimental groups: (A) TR antagonist 1-850 treatment for the duration of the experiment; (B) cells treated when growing as CL; (C) cells treated during the EB induction period; (D) cells treated during the differentiation phase as single cells obtained from EB; (E) control group of cells (not TR antagonist 1-850 treated). (B-E): Effect of TR antagonist 1-850 treatment in the RA-induced differentiation. (B-D): TR $\alpha$ and TR $\beta$ inhibition induced a reduction in the number of nestin-positive cells after 10DIV, EB and differentiating single cells obtained from EB being the RESC populations most affected. (E): Nestin RNA expression in single cells. RA induced an increase in the mRNA expression of nestin, which was downregulated by the TR antagonist 1-850. Graphs contain mean values \pm SEM from 2-3 independent experiments performed in duplicate. Statistical analysis performed: Student's $t$-test. Abbreviations: bFGF, basic fibroblast growth factor; CL, clusters; DIV, days in vitro; EB, embryoid bodies; LIF, leukemia inhibitory factor; RA, retinoic acid; SCML, stem cell medium with LIF; TR, thyroid hormone receptor.

We counted the nestin-positive cells after 10 DIV of differentiation, and results are shown in Figure $6 \mathrm{~B}-\mathrm{D}$. We first confirmed that RA is a key signaling molecule to induce neuroectodermal differentiation (Figure 6B), in fact less than 20\% of cells expressed nestin when RESC were differentiated without RA, compared to $40 \%$ in the presence of RA. TR antagonist 1-850 decreased the percentage of nestin-positive cells in culture conditions (c) and (d), corresponding to TR antagonist 1-850 exposure during EB induction or during differentiation as single cell (Figure 6D), in a similar \% effect. As a result, 
no differentiated single cells survived in condition a), in which the treatment lasted throughout all culture phases.

To confirm this result, and to explore the gene expression level, we treated single cells derived from EB with $1 \mu \mathrm{M}$ RA, $10 \mu \mathrm{M}$ TR antagonist 1-850, or both for 7 days, performing treatments every other day. As shown in Figure 6E, RA induced an increase in the expression of nestin mRNA of about 3-fold, whereas the TR antagonist 1-850 completely abolished the RA effect.

In order to investigate if TR antagonist 1-850 treatment may have an effect in the expression of TR-regulated genes, we studied the expression of Krüppel-like factor 9 (Klf9) mRNA, which is a TR-regulated gene [23,24]. We observed a significant increase of klf9 mRNA in the RA treated group of cells (Student's $t$ test, $p=0.0111$ ), however no significant effect was observed in the group of cells treated with TR-antagonist 1-850 (Supplemental Figure).

\section{Discussion}

During very early development of the embryo, before the onset of fetal thyroid gland function, THs of maternal origin reach the embryo through the feto-placental unit. However, emerging evidence indicates that THs may play an important role in very early embryonic development, for example forming part of the molecular machinery governing implantation from the maternal side. TR $\alpha 1$ and TR $\beta 1$ are expressed during the mid-luteal phase in glandular and luminal epithelium, increasing concomitantly until endometrial receptivity is established [25].

Very few studies have explored the potential role of TH signaling prior to implantation, i.e., at the morula-blastocyte stage. The little existing evidence suggesting that this developmental window may also be TH-sensitive include the expression of TR $\alpha 1$ and TR $\beta 1$ in the bovine cumulus cells, TR $\alpha$ expression in immature oocytes, and the improvement of bovine embryo development kinetics when oocytes are exposed to THs in vitro [26]. In bovine preimplantation embryos, TRs are expressed up to the blastocyst stage [17], as in human embryos, where the cells of the inner mass express low levels of TR $\alpha 1$ and TR $\beta 1$. THs stimulate mitochondria replication and energy production in human preimplantation embryos, by switching the glycolytic metabolic pathway to oxidative phosphorylation, and regulate the transcriptome [27].

The effect of THs on early development may be related to general cellular mechanisms (e.g., cell metabolism), but also to specific effects on cell differentiation and lineage. In this study, we explored this latter possibility, using in vitro systems based on ESCs. Since the 1980s, when in vitro methods for culturing ESCs first became available, great efforts have been dedicated to identifying the molecular mechanisms which contribute to the maintenance of their bona fide properties, self-renewal and pluripotential capabilities, including genetic and epigenetic factors and signaling pathways. In this study, we used a line of ESC obtained from rat (RESC), which had already been characterized for ESC bona fide properties [20]. The RESC populations CL, $\mathrm{mCL}$ and $\mathrm{mSC}$ were cultured in the presence of LIF, while EB were cultured in medium without LIF, which determines fate changes toward the three-layer lineage commitment. Notably, these culture conditions retained pluripotency marker expression, as indicated by Oct4, while Stella and Afp, both related to the three-layer lineage commitment [28,29], increased at the EB stage. These in vitro changes may resemble early in vivo embryo development, therefore this RESC model is a good candidate for the study of certain preimplantation embryo events.

We demonstrated that (i) in vitro RESC expressed nuclear receptor genes, in particular TRs and co-regulators; (ii) a robust switch toward increased expression of $\mathrm{TH}$ signaling molecules including synthesis and degrading enzymes and membrane transporters was observed at the EB stage; and (iii) THs played a key role in the neuroectodermal lineage induced by RA, since TR antagonists impaired RA-induced neuroectodermal differentiation.

Early embryos are highly sensitive to the environment under in vitro culture conditions, and the culture conditions can alter the gene expression pattern [30]. Both culture conditions we used to grow the RESC containing a very low T3 concentration (SCML-new about $300 \mathrm{pg} / \mathrm{mL}$ corresponding to $0.44 \mathrm{nM}$; SCM about $170 \mathrm{pg} / \mathrm{mL}$ corresponding to $0.25 \mathrm{nM}$ ), values similar to the physiological T3 concentration 
in oviduct and endometrial tissue $(0.67 \mathrm{nM})$ [19]. In fact, when $\mathrm{T} 3$ is used in vitro as a pharmacological tool, concentrations are usually 10 to 100 times higher [27,31]. Moreover, in studies demonstrating that TH exposure improves embryonic development by increasing the number and quality of formed embryos as well as the hatching rate, the culture media was supplemented with $\mathrm{T} 3$ at a concentration of nearly $74 \mathrm{nM}$ [19]. The T3 concentration able to induce lineage effects (oligodendroglial lineage from neural stem cells), was $50 \mathrm{nM}[32,33]$. Overall, analysis of the expression of genes and proteins related to $\mathrm{TH}$ signaling showed that the EB stage was more responsive to $\mathrm{TH}$ internalization (higher $\mathrm{TH}$ transporter expression) and trigger of the genomic effect (higher TR expression). Deiodinase expression was also imbalanced in favor of higher synthesis of the active form T3 (higher expression of D1 and D2 and lower expression of D3). Finally, the RA- and TH-mediated pathways seemed to be more highly represented, therefore we can speculate that a default genetic program establishes embryonic cell sensibility to THs of maternal origin. This hypothesis is supported by the fact that $\mathrm{T} 3$ concentration in the culture media across the expression switch (mSC to EB) did not change significantly, being 0.44 or $0.25 \mathrm{nM}$.

We then investigated whether the TH-priming of RESC was also implicated in lineage specification, and not simply limited to general metabolic functions of these cells [27]. In fact, at blastocyte stage, which is mimicked by EB, gastrulation occurs, and the three-layered embryonic structure is established. We focused on neuroectodermal specification, which is driven by RA, as extensively described in vivo and in vitro [34-36] and as also confirmed for RESC used in this study by the nestin marker [37]. $\mathrm{RA}$ is one of the most important extrinsic morphogens, modulating ESC differentiation into various cell types in a time- and concentration-dependent manner [36,38,39]. Cross-talk between TH and RA signaling has been documented under physiological conditions. In particular, unliganded TR $\alpha$ has an inhibitory effect on the RA response in mouse embryonic stem cells, inhibiting RAR $\beta$ expression and modulating RA-stimulated neural differentiation [40]. We first exposed RESC at all in vitro stages to both RA and the TR antagonist 1-850. The RA concentration we used for neuroectodermal induction $(1 \mu \mathrm{M})$ was within the range of concentrations used in other studies performed in EB from mouse ESC (from $10^{-8}$ to $10^{-6} \mathrm{M}$ ) $[34,36,39]$. We demonstrated that as soon as EB takes place, e.g., the three-layer induction stage of increasing complexity $[35,41]$ which corresponds to experimental conditions (c) and (d), RA cellular action requires TRs, suggesting that either RAR-TR nuclear receptor heterodimers or distinct, but simultaneously activated down-stream RAR and TR mechanisms are required for neuroectodermal induction. Future experiments will be performed to further investigate the role of RA and TH regulated pathways in this critical developmental stage.

\section{Materials and Methods}

\subsection{Cell Culture}

RESC were derived from the 4.5 days post coitum blastocyst as already described [20]. RESC-CL were grown without MEF in ULA (ultra-low attachment) plates in stem cell medium containing LIF supplemented with MEF conditioned medium (SCML-new) prepared as follows: Knockout DMEM (Dulbecco's Modified Eagles' Medium ES cells, Gibco, Waltham, MA, USA) supplemented with $50 \%$ MEF-CM (EmbryoMax ${ }^{\circledR}$ MEF Conditioned Media, Merck-Millipore Burlington, MA, USA), $5 \%$ FBS-ES (Fetal Bovine Serum Embryonic Stem cells tested, Euroclone, Milan, Italy), $0.1 \mathrm{mM}$ MEM/NEAA (Gibco), $0.1 \mu \mathrm{M} \beta$-mercaptoethanol, Nucleoside Mix $(8 \mu \mathrm{g} / \mathrm{mL}$ adenosine, $7.3 \mu \mathrm{g} / \mathrm{mL}$ cytidine, $8.5 \mu \mathrm{g} / \mathrm{mL}$ guanosine, $2.4 \mu \mathrm{g} / \mathrm{mL}$ thymidine, $7.3 \mu \mathrm{g} / \mathrm{mL}$ uridine, all from Sigma-Aldrich, Burlington, MA, USA), $100 \mathrm{U} / \mathrm{mL}$ penicillin, $100 \mu \mathrm{g} / \mathrm{mL}$ streptomycin (Thermo Fisher Scientific, Waltham, MA, USA), $2 \times 10^{3} \mathrm{U} / \mathrm{mL}$ LIF (leukemia inhibitor factor, Merck-Millipore, Burlington, MA, USA), $10 \mathrm{ng} / \mathrm{mL}$ bFGF (from Gibco, freshly added every $48 \mathrm{~h}$ ). Cells were mechanically split when they reached a size around $300 \mu \mathrm{m}$. Clusters from passage 54 to 56 (P54-56) were used for EB induction. Briefly, clusters were split and the resulting cells were grown in ULA plates in SCM without LIF but in the presence of bFGF. SCM medium was composed of DMEM:F12 (Dulbecco's Modified Eagle 
Medium: Nutrient Mixture F-12, Gibco), 10\% FBS embryonic stem cell quality, $0.1 \mathrm{mM}$ MEM/NEAA, $0.1 \mu \mathrm{M} \beta$-mercaptoethanol, Nucleoside Mix, $100 \mathrm{U} / \mathrm{mL}$ penicillin, $100 \mu \mathrm{g} / \mathrm{mL}$ streptomycin, $4 \mathrm{ng} / \mathrm{mL}$ bFGF (freshly added every $48 \mathrm{~h}$ ).

For the differentiation studies, EB at 7 DIV were split and the resulting single cells were cultured in SCM medium without mitogens (no LIF, no bFGF) to allow them to differentiate. Cells were seeded at a density of $1-5 \times 10^{4}$ cells $/ \mathrm{cm}^{2}$ and treated for 5 to 10 days, changing the medium every 3-4 DIVs. For ICC studies, single cells were plated onto $0.1 \%$ gelatin coated coverslip, whereas for gene expression studies on single cells, no surface coating was performed.

\subsection{Cell Treatments}

The thyroid hormone receptor antagonist (1-850) (Cayman Chemical, Ann Arbor, MI, USA), $10 \mu \mathrm{M}$, was used to block T3 binding to both TR $\alpha$ and TR $\beta$ [22]. Retinoic acid $(1 \mu \mathrm{M}$, all-trans RA, CAS N. 302-79-4, Sigma, Burlington, MA, USA) was used to induce neuroectoderm lineage differentiation. Both TR antagonist and RA were added to the culture medium every other day.

\section{3. $R T^{2} P C R$ Arrays}

To perform the PCR arrays, total RNA isolation from the RESC populations $\mathrm{CL}, \mathrm{mCL}, \mathrm{mSC}$ and EB was performed using the RNeasy Micro kit (Qiagen, Milan, Italy) according to manufacturer's instructions. Total RNA was quantified (Nanodrop 2000 spectrophotometer, Thermo Scientific, Waltham, MA, USA) and cDNA was produced using the RT $^{2}$ First Strand Kit (Qiagen) according to manufacturer's instructions. For each condition, a pool was created from independent experiments with a total of $1 \mu \mathrm{g}$ of RNA per group: $\mathrm{CL}, \mathrm{mCL}, \mathrm{mSC}$, and $\mathrm{EB}$.

The PCR array for rat nuclear receptors and coregulators was used (PARN-056Z; Qiagen) in combination with the $\mathrm{RT}^{2}$ SYBR Green qPCR Mastermix (Qiagen), and the online software GeneGlobe (Qiagen) was used to analyze data and produce the graphical representations. GAPDH and $\beta$-actin were used as housekeeping genes, according to the software instructions. A $\Delta \mathrm{Cq}$ of 37 was selected as cut-off for non-expressed genes.

All arrays passed the quality test with regard to reproducibility, positive control of PCR reaction, and genomic DNA contamination. Data was analyzed as $\Delta \mathrm{Cq}$ to build the clustergram and fold of regulation compared to a control group (CL). The differentially expressed genes $(n=25)$ were used as inputs for the pathway enrichment analysis using the GeneCodis software (v 4.0) and the KEGG algorithm.

\subsection{RNA Isolation, Reverse Transcription and Semi-Quantitative Real-Time PCR}

To perform the gene expression studies using classical qPCR, total RNA isolation was performed using the RNeasy Micro kit (Qiagen) and quantified as described above (Nanodrop 2000 spectrophotometer, Thermo Scientific). First-strand cDNA was prepared using the iScript ${ }^{\mathrm{TM}} \mathrm{CDNA}$ Synthesis Kit (BioRad, Hercules, CA, USA) according to manufacturer's instructions. A no-reverse transcribed RNA sample (no RT control) was also prepared as control.

Semi-quantitative real-time PCR reactions were performed in a final volume of $20 \mu \mathrm{L}$ consisting of $1 \times$ SYBR Green qPCR master mix (BioRad, Hercules, CA, USA) and $0.5 \mu \mathrm{M}$ forward and reverse primers using the CFX96 real-time PCR system (BioRad). Control samples (no RT and no template control) were processed for each pair of primers used. Details of the primer sequences is included in Table 1. All primers used were designed using Primer Blast software (NCBI, Bethesda, MD, USA) and synthesized by IDT (Coralville, IA, USA). GAPDH was used as housekeeping gene.

PCR reactions were performed through the following steps and thermal profile: (1) denaturation step ( $98^{\circ} \mathrm{C}, 3 \mathrm{~min}$ ); (2) amplification $\left(95^{\circ} \mathrm{C}\right.$ for $10 \mathrm{~s}$ and $60^{\circ} \mathrm{C}$ for $\left.60 \mathrm{~s}\right), 40$ cycles; (3) melting curve of the amplified products $\left(55^{\circ} \mathrm{C}\right.$ to $\left.95^{\circ} \mathrm{C}, \Delta \mathrm{t}=0.5^{\circ} \mathrm{C} / \mathrm{s}\right)$. The specificity of PCR reactions was evinced from the single peak obtained after performing the melting curve. Primer efficiency values for all primers were $95-102 \%$, therefore the $2(-\Delta \Delta \mathrm{Ct})$ method was used to perform the analysis 
Table 1. Sequences of primers used for real-time PCR. The name of the gene, the gene bank accession number as well as the forward and reverse primer sequence information are included in the table.

\begin{tabular}{|c|c|c|}
\hline Gene & Accession Number & Primer Sequence \\
\hline$A f p$ & NM_012493.2 & $\begin{array}{l}\text { Forward 5' - ATGAGTAGCGATGCGTTGGC -3' } \\
\text { Reverse 5'- GTCTGGAGCGGTCTTCTTGC -3' }\end{array}$ \\
\hline$D 1$ & NM_021653.4 & $\begin{array}{c}\text { Forward 5' - TCATTCAAGGCAGCAGACCC -3' } \\
\text { Reverse 5'- TGCCTGATGTCCACGTTGTT -3' }\end{array}$ \\
\hline$D 2$ & NM_031720.5 & $\begin{array}{l}\text { Forward 5' - CTCCTCAGCGTAGACTTG -3' } \\
\text { Reverse 5' - GTTCCAGACACAGCGTAG -3' }\end{array}$ \\
\hline D3 & NM_017210.4 & $\begin{array}{l}\text { Forward 5' - GCATCCGCAAGCATTTCC -3' } \\
\text { Reverse 5' - GGCATCTCCTCACCTTCA -3' }\end{array}$ \\
\hline GAPDH & NM_001113417.1 & $\begin{array}{l}\text { Forward 5' - TCATCCCTGCCTCTACTG -3' } \\
\text { Reverse } 5^{\prime} \text { - TGCTTCACCACCTTCTTG -3' }\end{array}$ \\
\hline MCT8 & NM_147216.1 & $\begin{array}{l}\text { Forward 5' - CAATGGTGTGGTGTCTGC -3' } \\
\text { Reverse 5' - CGGTAGGTGAGTGAGAGC -3' }\end{array}$ \\
\hline MCT10 & XM_017601535.1 & $\begin{array}{l}\text { Forward 5' - GGTGCAGCTGTAGGATTCGT -3' } \\
\text { Reverse 5' - AGAATGACCAGTGACGGCTG -3' }\end{array}$ \\
\hline Stella & NM_001047864 & $\begin{array}{c}\text { Forward 5' - GGTTCGTCTCCAGGTTAAG -3' } \\
\text { Reverse 5' - TCATCTCGTCTCTCATTTC - } 3^{\prime}\end{array}$ \\
\hline $\operatorname{TR} \alpha 1$ & NM_001017960 & $\begin{array}{l}\text { Forward 5'- GCAAACACAACATTCCGC-3' -3' } \\
\text { Reverse 5' - TCCTGATCCTCAAAGACCTC -3' }\end{array}$ \\
\hline $\operatorname{TR} \alpha 2$ & NM_031134 & $\begin{array}{l}\text { Forward 5' - GCAAACACAACATTCCGC -3' } \\
\text { Reverse 5' - CACCAAACTGCTGCTCAA -3' }\end{array}$ \\
\hline$T R \beta$ & NM_012672 & $\begin{array}{c}\text { Forward 5' - GCAAACACAACATTCCGC -3' } \\
\text { Reverse 5' - CACCAAACTGCTGCTCAA -3' }\end{array}$ \\
\hline Nestin & NM_001308239.1 & $\begin{array}{l}\text { Forward 5' - GGAGTGTCGCTTAGAGGTGC -3' } \\
\text { Reverse 5' - CAGCAGAGTCCTGTATGTAGCC -3' }\end{array}$ \\
\hline
\end{tabular}

\subsection{Immunocytochemistry}

Immunocytochemistry (ICC) was used to study the protein expression of RESC in floating growing cells (CL and EB) and in single cells (SC) obtained from EB growing as monolayer on a coated surface. Detailed descriptions of the primary and secondary antibodies used, working dilutions and supply companies are given in Table 2.

$C L$ and EB cryosection ICC: RESC growing in floating conditions (CL and EB) were processed for ICC following the procedure already described [42] with in-house modifications. In brief, cells were centrifuged $(400 \times g, 5 \mathrm{~min})$ at confluence and the supernatant was discarded. The cell pellet was incubated with $4 \%$ paraformaldehyde (PFA, in 0.1M Sørensen phosphate buffer, $\mathrm{pH} 7.4$ ) for $30 \mathrm{~min}$ at RT, then washed with PBS for $5 \mathrm{~min}$. Cells were then incubated with increasing \% sucrose solutions (10-20-30) for $30 \mathrm{~min}$ each at RT. After removing as much of the sucrose solution as possible, cells were initially embedded with OCT (Optimal Cutting Temperature) compound, then dry ice frozen and stored at $-80^{\circ} \mathrm{C}$ until processing. $14 \mu \mathrm{m}$ sections were prepared and mounted onto $200 \mathrm{mg} / \mathrm{mL}$ poly-L-lysine coated glass slides with a Cryostat (LEICA CM1950, Leica Biosystems, Milan, Italy). To perform the ICC, cryosections were air dried for $1 \mathrm{~h}$ at RT, then hydrated with PBS for $30 \mathrm{~min}$ at RT. After the blocking step (PBS/2\% BSA $/ 0.3 \%$ Triton-X 100 ), sections were incubated with primary antibodies at $4{ }^{\circ} \mathrm{C}$ overnight. After PBS washes (three times, $5 \mathrm{~min}$ each) and incubation with secondary antibodies for $30 \mathrm{~min}$ at RT, sections were incubated with the nuclear dye Hoechst $33258(1 \mu \mathrm{g} / \mathrm{mL}$ in PBS $/ 0.3 \%$ Triton-X 100) for $20 \mathrm{~min}$ at RT. Sections were finally washed with PBS (three times, $5 \mathrm{~min}$ each) and mounted in phenylenediamine solution (glycerol: PBS, 3:1, containing 0.1\% 1,4-phenylenediamine, $w / v$ ). 
Table 2. Primary and secondary antibodies. The antibodies used, the species in which they were produced, the dilutions at which they were used and the manufacturers are described in the table.

\begin{tabular}{ccccc}
\hline \multicolumn{5}{c}{ Primary Antibodies } \\
\hline Protein & Marker & Specie & Dilution & Company/Code \\
\hline AFP & Endoderm & Goat & $1: 50$ & S. Cruz Biotech./sc-130302 \\
\hline B-CG & Trophoblast & Goat & $1: 250$ & S. Cruz Biotech./sc-51605 \\
\hline D3 & TH signalling & Goat & $1: 50$ & S. Cruz Biotech./sc-69388 \\
\hline F-Actin & Cytoskeleton & Mouse & $1: 100$ & S. Cruz Biotech./SC-1616 \\
\hline Laminin & ECM & Rabbit & $1: 80$ & Sigma/L9393 \\
\hline Nestin & Neuroectoderm & Mouse & $1: 500$ & BD Pharmigen/556309 \\
\hline OCT 4 & Pluripotency & Rabbit & $1: 50$ & AbCam/ab19857 \\
\hline TR & TH signalling & Rabbit & $1: 500$ & Affinity Reagents/PA1-211A \\
\hline TR & TH signalling & Rabbit & $1: 500$ & Affinity Reagents/PA1-213A \\
\hline Target Specie & Host & Secondary Antibodies & \\
\hline Rabbit & Donkey & Rhodamine Red & $1: 200$ & Jackson Lab./711-295-152 \\
\hline Mouse & Goat & DyLight 488 & $1: 200$ & Thermo Scient./35502 \\
\hline Goat & Donkey & Rhodamine Red & $1: 200$ & Jackson Lab./705-295-147 \\
\hline
\end{tabular}

Abbreviations: AFP, Alpha fetoprotein; $\beta$-CG, Chorionic Gonadotropin beta; D3, deiodinase type 3; ECM, extracellular matrix; Jackson Lab.: Jackson Laboratories, Bar Harbor, ME, USA; OCT 4, Octamer-binding transcription factor 4; S. Cruz Biotech.: Santa Cruz Biotechnology; Thermo Scient.: Thermo Scientific; TH, thyroid hormone; TR $\alpha$ thyroid hormone receptor alpha-1; TR $\beta 1$ thyroid hormone receptor beta 1 .

Single cell ICC: cells were fixed with 4\% PFA solution (30 min at RT) and washed three times with PBS for 5 min. After incubating with blocking solution (PBS/2\% BSA/0.3\% Triton-X 100), cells were incubated with primary antibodies at $4{ }^{\circ} \mathrm{C}$ overnight. After PBS washes (three times, 5 min each) and incubation with secondary antibodies for $30 \mathrm{~min}$ at RT, cells were incubated with Hoechst $33258(1 \mu \mathrm{g} / \mathrm{mL}$ in PBS/0.3\% Triton-X 100) for $20 \mathrm{~min}$ at RT. After washing, cells were mounted in phenylenediamine solution. Control experiments with the secondary antibodies alone were always carried out in parallel (results not shown). Staining was observed using an Eclipse E600 microscope (Nikon, Minato, Tokyo, Japan).

\subsection{T3, T4 Quantification}

T3 was quantified in the two culture media used, SCML-new for CL, mSC and mCL populations, and SCM for the EB and single cells obtained from them. The xMAP Luminex technology and the Rat Thyroid Magnetic Bead Panel-Endocrine Multiplex Assay kit (RTHYMAG-30K, Merck Millipore) were used, according to manufacturer's instructions with appropriate in-house modifications. MAGPIX instrument and XPONENT 4.2 software were used to read the bead fluorescence and perform the analysis.

\subsection{Statistical Analysis}

Data is expressed as mean \pm sem. Statistical analysis was performed with anova-1 way and tukey's multiple comparison test to compare the different experimental resc groups. Student's $t$-test was used to compare the two experimental groups. Significance was set at $p<0.05$.

\section{Conclusions}

We demonstrated that embryonic stem cells derived from rat blastocytes progressively increased TH signaling genes in vitro depending on culture conditions, leading to "embryonic bodies" and in vitro 3D structures resembling blastocytes. Moreover, TH nuclear signaling is essential to allow RA-mediated neuroectodermal differentiation. 
Supplementary Materials: The following are available online at http://www.mdpi.com/1422-0067/21/23/8945/s1, Figure S1: Klf9 gene expression after RA and TR antagonist 1-850 treatment, Table S1: List of genes and fold regulations, Table S2: Pathway enrichment analysis.

Author Contributions: Conceptualization, L.L. and L.G.; methodology, M.F., M.P., V.A.B., A.F., G.A.; formal analysis, M.F., M.P., V.A.B.; writing-original draft preparation, M.F.; writing-review and editing, L.C.; supervision, L.C.; funding acquisition, L.G. All authors have read and agreed to the published version of the manuscript.

Funding: This research was funded by Progetto Regione Emilia Romagna DGR N. 1680 DEL 14/10/2019 (PI: LG).

Conflicts of Interest: The authors declare no conflict of interest.

\section{Abbreviations}

$\begin{array}{ll}\text { AfP } & \text { Alpha Fetoprotein } \\ \text { CL } & \text { Clusters } \\ \text { D1 } & \text { Deiodinase type-1 } \\ \text { D2 } & \text { Deiodinase type-2 } \\ \text { D3 } & \text { Deiodinase type-3 } \\ \text { EB } & \text { Embryoid body/ies } \\ \text { ESC } & \text { Embryonic stem cells } \\ \text { LIF } & \text { Leukemia inhibitory factor } \\ \text { MCT10 } & \text { Monocarboxylate transporter 10 } \\ \text { MCT8 } & \text { Monocarboxylate transporter } 8 \\ \text { mCL } & \text { Clusters from the mixed population } \\ \text { mSC } & \text { Single cells from the mixed population } \\ \text { Oct } 4 & \text { Octamer-binding transcription factor } 4 \\ \text { RESC } & \text { Rat embryonic stem cells } \\ \text { SC } & \text { Single cells } \\ \text { T3 } & 3,3^{\prime}, 5 \text {-Triiodo-L-thyronine } \\ \text { T4 } & 3,5,3^{\prime}, 5^{\prime} \text {-Tetraiodothyronin } \\ \text { TR } & \text { Thyroid hormone receptor } \\ \text { ULA } & \text { Ultra-low attachment }\end{array}$

\section{References}

1. Li, M.; Eastman, C.J. The changing epidemiology of iodine deficiency. Nat. Rev. Endocrinol. 2012, 8, 434-440. [CrossRef] [PubMed]

2. Batistuzzo, A.; Ribeiro, M.O. Clinical and subclinical maternal hypothyroidism and their effects on neurodevelopment, behavior and cognition. Arch. Endocrinol. Metab. 2020, 64, 89-95. [CrossRef] [PubMed]

3. Chen, Z.-P.; Hetzel, B.S. Cretinism revisited. Best Pr. Res. Clin. Endocrinol. Metab. 2010, 24, 39-50. [CrossRef] [PubMed]

4. Calzà, L.; Fernández, M.; Giardino, L. Role of the Thyroid System in Myelination and Neural Connectivity. Compr. Physiol. 2015, 5, 1405-1421. [CrossRef]

5. Lorenzini, L.; Fernández, M.; Baldassarro, V.A.; Bighinati, A.; Giuliani, A.; Calzà, L.; Giardino, L. White Matter and Neuroprotection in Alzheimer's Dementia. Molecules 2020, 25, 503. [CrossRef]

6. Lazar, M.A. Maturing of the nuclear receptor family. J. Clin. Investig. 2017, 127, 1123-1125. [CrossRef]

7. Evans, R.M.; Mangelsdorf, D.J. Nuclear Receptors, RXR, and the Big Bang. Cell 2014, 157, 255-266. [CrossRef]

8. Calzà, L.; Baldassarro, V.A.; Fernández, M.; Giuliani, A.; Lorenzini, L.; Giardino, L. Thyroid Hormone and the White Matter of the Central Nervous System: From Development to Repair. Vitam. Horm. 2018, 253-281. [CrossRef]

9. Davis, P.J.; Leonard, J.L.; Lin, H.-Y.; Leinung, M.; Mousa, S.A. Molecular Basis of Nongenomic Actions of Thyroid Hormone. In Vitamins and Hormones; Elsevier BV: Amsterdam, The Netherlands, 2018; Volume 106, pp. 67-96.

10. Quadro, L.; Spiegler, E.K. Maternal-Fetal Transfer of Vitamin A and Its Impact on Mammalian Embryonic Development. In Subcellular Biochemistry; Asson-Batres, M., Rochette-Egly, C., Eds.; Springer Science and Business Media LLC.: Berlin, Germany, 2020; Volume 95, pp. 27-55. 
11. Le Maire, A.; Teyssier, C.; Balaguer, P.; Bourguet, W.; Germain, P.; Maire, L. Regulation of RXR-RAR Heterodimers by RXR- and RAR-Specific Ligands and Their Combinations. Cells 2019, 8, 1392. [CrossRef]

12. Landers, K.; Richard, K. Traversing barriers-How thyroid hormones pass placental, blood-brain and blood-cerebrospinal fluid barriers. Mol. Cell. Endocrinol. 2017, 458, 22-28. [CrossRef]

13. Asson-Batres, M.A. How Dietary Deficiency Studies Have Illuminated the Many Roles of Vitamin A During Development and Postnatal Life. In Subcellular Biochemistry; Springer Science and Business Media LLC.: Berlin, Germany, 2020; Volume 95, pp. 1-26.

14. Rochette-Egly, C. Retinoic Acid-Regulated Target Genes During Development: Integrative Genomics Analysis. In Subcellular Biochemistry; Springer Science and Business Media LLC.: Berlin, Germany, 2020; Volume 95, pp. 57-85.

15. Patel, J.; Landers, K.; Li, H.; Mortimer, R.H.; Richard, K. Delivery of maternal thyroid hormones to the fetus. Trends Endocrinol. Metab. 2011, 22, 164-170. [CrossRef] [PubMed]

16. Cai, Y.Y.; Lin, N.; Zhong, L.P.; Duan, H.J.; Dong, Y.H.; Wu, Z.; Su, H. Serum and follicular fluid thyroid hormone levels and assisted reproductive technology outcomes. Reprod. Biol. Endocrinol. 2019, 17, 90-98. [CrossRef] [PubMed]

17. Rho, N.-Y.; Ashkar, F.A.; Revay, T.; Madan, P.; Rho, G.-J.; King, W.A.; Favetta, L.A. De novo transcription of thyroid hormone receptors is essential for early bovine embryo development in vitro. Reprod. Fertil. Dev. 2018, 30, 779-788. [CrossRef] [PubMed]

18. Drakakis, P.; Vlismas, A.; Partsinevelos, G.; Desmarais, B.; Bletsa, R.; Kallianidis, K.; Loutradis, D.; Antsaklis, A.; Kiessling, A. O-014 Gene Expression of Hormones and Hormone Receptors and Growth Factors and Receptors in 8Cell Human Embryos-Their Role in Early Embryonic Development. 2010. Available online: https://insights.ovid.com/hurep/201006001/00004683-201006001-00017 (accessed on 24 November 2020).

19. Ashkar, F.A.; Semple, E.; Schmidt, C.H.; John, E.S.; Bartlewski, P.M.; King, W.A. Thyroid hormone supplementation improves bovine embryo development in vitro. Hum. Reprod. 2009, 25, 334-344. [CrossRef]

20. Fernández, M.; Pirondi, S.; Chen, B.L.; Del Vecchio, G.; Alessandri, M.; Farnedi, A.; Pession, A.; Feki, A.; Jaconi, M.E.; Calza, L. Isolation of rat embryonic stem-like cells: A tool for stem cell research and drug discovery. Dev. Dyn. 2011, 240, 2482-2494. [CrossRef]

21. Pannella, M.; Giardino, L.; Calzà, L.; Fernández, M. Growth and Neurotrophic Factors in Embryonic Stem Cells. Methods Mol. Biol. 2018, 1727, 275-294. [CrossRef]

22. Schapira, M.; Raaka, B.M.; Das, S.; Fan, L.; Totrov, M.; Zhou, Z.; Wilson, S.R.; Abagyan, R.; Samuels, H.H. Discovery of diverse thyroid hormone receptor antagonists by high-throughput docking. Proc. Natl. Acad. Sci. USA 2003, 100, 7354-7359. [CrossRef]

23. Cvoro, A.; DeVito, L.; Milton, F.A.; Noli, L.; Zhang, A.; Filippi, C.; Sakai, K.; Suh, J.H.; Sieglaff, D.H.; Dhawan, A.; et al. A Thyroid Hormone Receptor/KLF9 Axis in Human Hepatocytes and Pluripotent Stem Cells. Stem Cells 2015, 33, 416-428. [CrossRef]

24. Tagliaferri, D.; Mazzone, P.; Noviello, T.M.R.; Addeo, M.; Angrisano, T.; Del Vecchio, L.; Visconte, F.; Ruggieri, V.; Russi, S.; Caivano, A.; et al. Retinoic Acid Induces Embryonic Stem Cells (ESCs) Transition to 2 Cell-Like State Through a Coordinated Expression of Dux and Duxbl1. Front. Cell Dev. Biol. 2020, 7. [CrossRef]

25. Colicchia, M.; Campagnolo, L.; Baldini, E.; Ulisse, S.; Valensise, H.; Moretti, C. Molecular basis of thyrotropin and thyroid hormone action during implantation and early development. Hum. Reprod. Updat. 2014, 20, 884-904. [CrossRef]

26. Costa, N.; Cordeiro, M.; Silva, T.; Sastre, D.; Santana, P.; Sá, A.; Sampaio, R.; Santos, S.; Adona, P.; Miranda, M.S.; et al. Effect of triiodothyronine on developmental competence of bovine oocytes. Theriogenology 2013, 80, 295-301. [CrossRef] [PubMed]

27. Noli, L.; Khorsandi, S.E.; Pyle, A.; Giritharan, G.; Fogarty, N.; Capalbo, A.; DeVito, L.; Jovanovic, V.M.; Khurana, P.; Rosa, H.; et al. Effects of thyroid hormone on mitochondria and metabolism of human preimplantation embryos. Stem Cells 2019, 38, 369-381. [CrossRef] [PubMed]

28. Wongtrakoongate, P.; Jones, M.; Gokhale, P.J.; Andrews, P.W. STELLA Facilitates Differentiation of Germ Cell and Endodermal Lineages of Human Embryonic Stem Cells. PLoS ONE 2013, 8, e56893. [CrossRef] [PubMed] 
29. Ghosheh, N.; Olsson, B.; Edsbagge, J.; Küppers-Munther, B.; Van Giezen, M.; Asplund, A.; Andersson, T.B.; Björquist, P.; Carén, H.; Simonsson, S.; et al. Highly Synchronized Expression of Lineage-Specific Genes duringIn VitroHepatic Differentiation of Human Pluripotent Stem Cell Lines. Stem Cells Int. 2016, 2016, 1-22. [CrossRef] [PubMed]

30. Assou, S.; Boumela, I.; Haouzi, D.; Anahory, T.; Dechaud, H.; De Vos, J.; Hamamah, S. Dynamic changes in gene expression during human early embryo development: From fundamental aspects to clinical applications. Hum. Reprod. Updat. 2010, 17, 272-290. [CrossRef] [PubMed]

31. Singh, A.K.; Prakash, C.; Rohit, K.; Santra, A.; Das, S.K. Cattle Embryos Development through In Vitro Techniques Using Thyroxine Hormone as a Culture Media Supplement. 2020. Available online: www.isgbrd. co.in (accessed on 24 November 2020).

32. Fernández, M.; Paradisi, M.; Del Vecchio, G.; Giardino, L.; Calza, L. Thyroid hormone induces glial lineage of primary neurospheres derived from non-pathological and pathological rat brain: Implications for remyelination-enhancing therapies. Int. J. Dev. Neurosci. 2009, 27, 769-778. [CrossRef] [PubMed]

33. Baldassarro, V.A.; Krężel, W.; Fernández, M.; Schuhbaur, B.; Giardino, L.; Calzà, L. The role of nuclear receptors in the differentiation of oligodendrocyte precursor cells derived from fetal and adult neural stem cells. Stem Cell Res. 2019, 37, 101443. [CrossRef]

34. Manuilova, E.S.; Gordeeva, O.F.; Grivennikov, I.A.; Ozernikov, N.D. Embrional'nye Stvolovye Kletki: Spontannaia i Napravlennaia Differentsirovka. 2001. Available online: https://pubmed.ncbi.nlm.nih.gov/ 15926336/ (accessed on 24 November 2020).

35. Engberg, N.; Kahn, M.; Petersen, D.R.; Hansson, M.; Serup, P. Retinoic Acid Synthesis Promotes Development of Neural Progenitors from Mouse Embryonic Stem Cells by Suppressing Endogenous, Wnt-Dependent Nodal Signaling. Stem Cells 2010, 28, 1498-1509. [CrossRef]

36. Okada, Y.; Shimazaki, T.; Sobue, G.; Okano, H. Retinoic-acid-concentration-dependent acquisition of neural cell identity during in vitro differentiation of mouse embryonic stem cells. Dev. Biol. 2004, 275, 124-142. [CrossRef]

37. Wiese, C.; Rolletschek, A.; Kania, G.; Blyszczuk, P.; Tarasov, K.V.; Tarasova, Y.; Wersto, R.P.; Boheler, K.R.; Wobus, A.M. Nestin expression-A property of multi-lineage progenitor cells? Cell. Mol. Life Sci. 2004, 61, 2510-2522. [CrossRef]

38. Guan, K.; Chang, H.; Rolletschek, A.; Wobus, A.M. Embryonic stem cell-derived neurogenesis. Cell Tissue Res. 2001, 305, 171-176. [CrossRef] [PubMed]

39. Rohwedel, J.; Guan, K.; Wobus, A.M. Induction of cellular differentiation by retinoic acid in vitro. Cells Tissues Organs 1999, 165, 190-202. [CrossRef] [PubMed]

40. Lee, K.K.H.; Li, F.C.H.; Young, W.T.; Kung, J.L.S.; Ng, J.L.; Cheah, K.S.E. Influence of digits, ectoderm, and retinoic acid on chondrogenesis by mouse interdigital mesoderm in culture. Dev. Dyn. 1994, 201, 297-309. [CrossRef] [PubMed]

41. Liyang, G.; Abdullah, S.; Rosli, R.; Nordin, N. Neural Commitment of Embryonic Stem Cells through the Formation of Embryoid Bodies (EBs). Malays. J. Med Sci. 2015, 21, 8-16.

42. Gomes, I.C.; Acquarone, M.; Maciel, R.D.M.; Erlich, R.B.; Rehen, S.K. Analysis of Pluripotent Stem Cells by using Cryosections of Embryoid Bodies. J. Vis. Exp. 2010, 2344. [CrossRef]

Publisher's Note: MDPI stays neutral with regard to jurisdictional claims in published maps and institutional affiliations.

(C) 2020 by the authors. Licensee MDPI, Basel, Switzerland. This article is an open access article distributed under the terms and conditions of the Creative Commons Attribution (CC BY) license (http://creativecommons.org/licenses/by/4.0/). 